\title{
A PLEA FOR THE UNPRINCIPLED DECISION
}

\section{Charles E. Clark*}

Not so very many years ago, when legislative action was rather freely negatived by the Supreme Court, the voices of liberals like Holmes called for judicial self-restraint. Since that time, a more conservative self-restraint doctrine which strictly limits the role of judicial review bas gained wide support. Judge Clark argues that such a doctrine cannot be used to avoid decision-making on the ground that the issues are lacking in adequate generality to permit of impartial or "principled" decisions, because these are concepts which are too vague and ambiguous for practical use and tend merely to support conservative decision-making. In this Article be registers bis plea for the "unprincipled" decision.

$7 \mathrm{HE}$ invitation to join in a symposium honoring Dean Ribble on 1 his retirement must be taken as a command; his eminent position as a law school professor and administrator and as a constitutional scholar requires that we bring to him on this important occasion the finest garlands of which we are capable. But very busy activity as a working judge has not left me opportunity for new contemplation and reflection, and I must needs return to a subject upon which others have written much and I, too, have transgressed. ${ }^{1}$ My defense must be that the subject is one of vast importance, and after all it does lie within the Dean's specialty of constitutional decision.

It is now of course a truism that the Supreme Court lives in an existence of crisis; its position of unique authority in our government system requires as much. Many of us still have vividly in mind the crisis of the thirties in which we lived and participated. Observers now profess with considerable reason to see another major crisis at hand. One striking difference from the earlier one may be noted. Then the law school world-precursor and prophet of the future-was rather solidly arrayed against the original majority trend of the era. Now the

* Judge, United States Court of Appeals for the Second Circuir; former dean of Yale Law School. B.A., 1911, LL.B., 1913, Yale University.

1. Clark, The Limits of Judicial Objectivity, 12 AM. U.L. Rev. 1 (1963); Clark, Federal Procedural Reform and States' Rights; to a More Perfect Union, 40 Texas L. Rev. 211 (1961); Clark \& Trubek, The Creative Role of the Judge: Restraint and Freedom in the Common Law Tradition, 71 YALE L.J. 255 (1961). The contributions of others are cited in the footnotes below. 
law schools (as well as the Court) seem quite divided; indeed a particularly articulate view, expressed on the Court by Felix Frankfurter as the successor of the liberal tradition of the great Holmes, appears to have the dynamic support of the Harvard Law School itself. ${ }^{2}$ Whatever else may be said for the present debate, it seems more vital and alive than does the earlier division, at least in retrospect.

Like most debates, this one is simplified by the use of labels which express a partial, if too black-and-white, truth. The division is said to be between those who would have the Court move actively in support of individual rights and liberties and those who would have the Court act with restraint, bowing to the legislature as the effective tool for execution of the popular will, between the "libertarians" or "activists" and the "humilitarians," to employ a possibly invidious term used by a supporter. ${ }^{3}$ Of course the lines are not rigid, and the justices cannot be found invariably on one side or the other. But there is a difference in philosophy which is shown generally in results. Thus the point of restraint has been traced to Holmes' reiterated view of the freedom which should be accorded the legislatures, state and national, to act or to experiment in the public interest. And more lately this restraint has been given a philosophical principle of a turning "Toward Neutral Principles of Constitutional Law" in the already classic discussion by Professor Wechsler in the Holmes Lectures at Harvard in 1959.4

This brilliant analysis has provoked notable discussion which need not be retraced here. Rather it is my purpose to consider a portion of the argument as it bears on the daily task of judicial decision. Before turning specifically to this task, however, I beheve it well to consider, even though briefly and partially, the philosophy of the brilliant and complex scholar who is the chief judicial exponent of self-restraint. To many, Justice Frankfurter's judicial career has fallen short of its earlier promise because he has seemed not to press for the liberal point of view to which his previous career had pointed. It is clear, however,

2. Griswold, Foreword: Of Time and Attitudes-Professor Hart and Judge Arnold, 74 Harv. L. Rev. 81 (1960); Griswold, Felix Frankfutter-Teacher of the Law, 76 Harv. L. REv. 7, 12 (1962); Hart, Foreword: The Time Chart of the Justices, 73 HARv. L. REv. 84 (1959). The learned authors took particular exception to the review of state (and federal) court limitations on jury trials in FELA cases which to the writer seems 2 most peculiar and undesirable restriction on the enforcement of fundamental rights. See Arnold, Professor Hart's Theology, 73 Harv. L. Rev. 1298 (1960).

3. Mendeison, Justices Black and Frankfurter: Conflict in the Court (1961). For critical reviews of this book, see note 6 infra.

4. 73 Harv. L. Rev. 1 (1959), reprinted in Wechsler, Principles, Polstics, ANd FundaMENTAL LAW 3 (1961). 
that the Justice has a fully developed philosophy which is complete to him and unanswerable in the eyes of his supporters. ${ }^{5}$ So any query of the validity of "neutral principles" as the touchstone of "principled decision" may properly start with a consideration of Justice Frankfurter's philosophy of restraint.

While this intriguing subject has called forth much comment and will undoubtedly stimulate more as the years pass and the Justice's notable career recedes into history, yet I have found the most stimulating questions for my present task raised in a book review. This is Professor Harry Kalven's review in the Indiana Law Journal of Professor Mendelson's notably one-sided monograph entitled, "Justices Black and Frankfurter: Conflict in the Court." "Professor Kalven pays tribute to the depth of the Justice's feeling, shown, for example, in his dissent in the second flag salute case, ${ }^{7}$ and then asks some pertinent questions as to the ultimate consequence and value of the result. Thus he says: "And again does the Franlkfurterian judicial review make any sense as a political institution-why should any one have preferred the setting up of this anemic check to the simplicity of not having judicial review at all?" 8 This puts it in a nutshell-why sloould Marshall have won his historic controversy with Jefferson over Marbury $v$. Madison? Indeed, why should Marshall have written at all, and particularly why should he have written his great nationalistic and unifying decisions? And is this "anemic check" all that history yields for present-day guidance?

So Professor Kalven raises the question as to whetler Frankfurter is actually carrying on the Holmes tradition:

Finally, there is the tantalizing problem of Justice Frankfurter's emulation of and admiration for Justice Holmes. The question simply is whether Holmes can properly be bis hero and model. The difficulties here, I take it, are more with Holmes than with Frankfurter. Holmes as a judge was not introspectively concerned with the power be was

5. Thus this is a major theme of the essays in 76 Harv. L. Rev. 1-24 (1962), honoring the Justice on the occasion of his retirement from the Court and of his eightieth birthday. "For one of the things that shines brightly and consistently throughout the whole of Mr. Justice Frankfurter's judicial work is a fierce determination to keep his own ideologies and predilections out of the decision of cases." Harlan, The Frankfurter Imprint as Seen by a Colleague, 76 Harv. L. Rev. 1, 2 (1962). Compare also the book review by former Attorney General Biddle, 75 HaRv. L. Rev. 1042 (1962).

6. 37 IND. L.J. 572 (1962). Somewhat similar views are expressed in a review of this same book by Dean Alfange, Jr., 72 Yale L.J. 207 (1962); cf. Gordon, Book Review, 61 Colum. L. Rev. 1537 (1961). But see Biddle, supra note 5.

7. West Virginia State Bd. of Educ. v. Barnette, 319 U.S. 624 (1943).

8. 37 IND. L.J. 572, 577 (1962). 
exercising. His flair for epigrammatic brevity not only made him a judicial stylist quite different from Justice Frankfurter but it led, as for example in Eisner v. Macomber or Buck v. Bell, to simplistic short cuts Justice Frankfurter would have found abhorrent.9

In short, is it realistic or even adequate to hold Holmes more interested in a particular rationale than in the result he was achieving and to conclude that whatever the difference in time and setting he would nevertheless sacrifice result to ironclad rationale?

At any rate, the Frankfurter supporters have accepted the results (perhaps a bit blindly) and have given as their greatest tribute his passion for legislative freedom, which is translated as keeping his own personal convictions out of the pending case. ${ }^{10}$ But this is not enough. It does leave many things to be explained, of which his concurrence in the school segregation decision, Brown v. Board of Educ., ${ }^{11}$ is a sharp example. And the thesis, starkly stated, with no indicated exception, repudiates so much of Supreme Court history, indeed of American history, as to leave a gap which appears to be trouble-breeding. So we have the present-day search for a rationale which will permit the Court to be eclectic in its activism. The most ambitious attempt thus far is Professor Wechsler's Holmes Lecture mentioned above, ${ }^{12}$ which would find the touchstone in developing "neutral principles of constitutional law."

While Professor Wechsler's immediate audience appears to have been scholars and students, I think it clear he had in mind a normative purpose to instruct and to admonish as to proper ways of constitutional right-living. And here his target must have been judges and notably Supreme Court Justices. We are advised to refrain from deciding issues lacking adequate generality or neutrality to permit of impartial or "principled" decisions. In common with others ${ }^{13}$ I have found it difficult to make the distinctions work in practical judicial life, and I may well

\section{Ibid.}

10. See note 5 supra. Compare the intriguing and shrewd discussion of judicial "modesty" in Shapiro, Judicial Modesty, Political Reality, and Preferred Position, 47 CORNELL L. Q. 175 (1962).

11. 347 U.S. 483 (1954).

12. Wechsler, Toward Neutral Principles of Constitutional Law, supra note 4.

13. Rostow, American Legal Realism and the Sense of the Profession, 34 RockY Mr. L. Rev. 123, 136-46 (1962), reprinted in Rostow, The Sovereign Prerogative: The Suprenie Court and the Quest for Law 3, 24-39 (1962). See also Henson, A Criticism of Criticism: In re Meaning, 29 Fordhanr L. Rev. 553 (1960); Miller \& Howell, The MIyth of Neutrality in Constitutional Adjudication, 27 U. CHI. L. Rev. 661 (1960); Mueller \& Schwartz, The Principle of Neutral Principles, 7 U.C.L.A.L. Rev. 571 (1960); and my articles cited note 1 supra. 
have done less than justice to his proposed interpretation. I have found much help, however, in Professor Golding's article in the Columbia Law Review, "Principled Decision-Making and the Supreme Court," 14 an article most sympathetic in intent and tone, but leaving, if I may so suggest, a fairly limited field of operations for the neutrality principle. Perhaps I oversimplify, but the net result does appear to be that the principled decision is one which follows the beaten track rather closely, while a decision without precedent, breaking new ground, must be unprincipled. (Obviously this has no preceptible tie to judicial "integrity," as has apparently been assumed; ${ }^{15}$ but it does appear to be closely tied to stare decisis and the rule of precedent.) This is the only way I can explain Professor Wechsler's deep worry as to how to analyze the school desegregation case. Undoubtedly the same worries would assail him as to the voter apportionment case, Baker v. Carr. ${ }^{16}$

There is an initial difficulty in perceiving how a court may pick and choose among issues before it and leave some undecided. True, the Supreme Court has ways not available to the lower courts to refuse adjudication, of which its discretion in declining to grant certiorari in cases of comparatively little moment is the most important. ${ }^{17}$ But even this power may seem greater than it is in actuality in this area of new and original cases. For the normal pressures from the courts below and from public opinion generally will soon require it to accept a case and face the problem. The steps leading up to the unexpected Baker v. Carr decision well illustrated this. But with us in the constitutionally "inferior" courts, we are rather expected to take all comers. And if a court tries to avoid an issue by deciding in the negative or for the defendant, why that is a decision, a negative precedent, of often farreaching inport. ${ }^{18}$ There is no way that decision can be avoided; there is only a kind of pressure-even presumption-to choose what seems the side closest to precedent and past action. And that means a conservative vote for inaction and the status quo. It is a sad, but little noticed, fact that neutral principles eventually push to re-enforce the dead hand of the law and the rule of the past.

14. 63 Colum. L. Rev. 35 (1963).

15. Cf. Black, The Lawfulness of the Segregation Decisions, 69 YaLE L.J. 421 (1960); Pollak, Racial Discrimination and Judicial Integrity; A Reply to Professor Wechsler, 108 U. PA. L. REv. 1 (1959).

16. 369 U.S. 186 (1962).

17. Other means, as well as the situation of lower courts, are discussed in BickEL, The Passive Virtues, in The Least Dangerous Branch 111-98 (1962).

18. The meaning and effect of a negative decision is discussed in Clark, The Limits of Judicial Objectivity, 12 Am. UL. Rev. 1, 7-8 (1963), citing Cook, The Associated Press Case, 28 Yale L.J. 387, 391 (1919). 
Here, therefore, is my deeply felt, even if not particularly original, argument. We need the unprincipled decision, i.e., the unprecedented and novel decision as I find it defined above, to mark judicial progress, of the kind in fact which has been a glorious heritage of the Court's history. The great nationalistic decisions of John Marshall are a prime example. In the light of their time, how could Gibbons $v$. Ogden ${ }^{19}$ or McCullocb v. Maryland ${ }^{20}$ be considered anything but "unprincipled decisions"? But how the history of the country would have been changed, the Supreme Court lessened in authority, and our government hampered and restricted, without them.

I expect my readers will find it now unbelievable that those great decisions will falter by any test, be it neutral principle or otherwise. But the logic of these critics does seem to carry us just that far. Even if I may have erred in this analysis of their views, the obvious cautionary admonition for the justice or judge is clearly there, whatever the explanation of a particular case may be. And that is what I fear the most and why I speak out here once more. It seems that-unlike the thirtiesthe conservative approach has become the respectable one, even honored by the tribute of the Holmes Lectures. Rendered doubtful accordingly are such things as Dean Rostow's superb defense of "The Democratic Character of Judicial Review," ${ }^{21}$ an essay persuasively explaining how the institution of judicial review has fitted into the popular ideals of the American people. For judicial review also is at variance with strictly neutral principles. For my part I do not fear to be governed by "Plato's wise men," or even replicas of them; ${ }^{22}$ I do fear to be left to the tender mercies of judges who shiver to take the responsibility of forthright decision along lines never before attempted.

And so I make my plea for the unprincipled decision. Of course I do not suggest a wild orgy of unexpected and unwise judicial excursions. But elderly judges are so conditioned by training and tradition that the danger of that is minuscule. As experience has demonstrated so often, the danger of conservatism is not. So let us have more decisions in the tradition of Gibbons v. Ogden and Baker v. Carr.

19. 22 U.S. (9 Wheat.) 1 (1824).

20. 17 U.S. (4 Wheat.) 316 (1819).

21. 66 Harv. L. Rev. 193 (1952), reprinted in Rostow, The Sovereign Prerogative: The Suprene Court and the QUesT For LAw 147-92 (1962).

22. This is a reference to the concern expressed by Judge Hand and Dean Griswold as noted in Clark, The Limits of Judicial Objectivity, 12 AM. U.L. Rev. 1, 12-13 (1963). See Hand, The Bill of Rights 73 (1958); Griswold, Foreword: Of Time and AttitudesProfessor Hart and Judge Arnold, 74 Harv. L. Rev. 81, 93 n.48 (1960). Compare Bickel, The Least Dangerous Branch 20 (1962). 